\title{
Effect of different doses of biological preparation Meganit Nirbator on greenhouse gas emissions from chicken manure
}

\author{
Vorobel M. ${ }^{1}$, Kaplinskiy V. ${ }^{2}$, Pinchuk V. ${ }^{3}$, Dmytrotsa A. ${ }^{4}$ \\ 1, 2, 4 Institute of Agriculture of Carpathian region of NAAS \\ 5, Hrushevskoho Str., vil. Obroshyne, Pustomytiv region, Lviv oblast, 81115, Ukraine \\ ${ }^{3}$ Institute of Agroecology and Natural Management of NAAN \\ 12, Metrolohichna Str., Kyiv, 03143, Ukraine \\ e-mail: 1vorobelmariia@gmail.com, ${ }^{2}$ vasyl.kaplinskiy@gmail.com, ${ }^{3}$ pinchuk_vo@ukr.net, \\ ${ }^{4}$ andrianadmitroca@gmail.com \\ ORCID: ${ }^{10000-0003-4387-4173, ~}{ }^{2} 0000-0002-0138-9957$, \\ ${ }^{3} 0000-0003-0646-1580,{ }^{4} 0000-0003-3304-3691$
}

\begin{abstract}
Goal. To determine the effectiveness of different doses of the biological preparation Meganit Nirbator on the emission of greenhouse gases $(\mathrm{CH} 4, \mathrm{CO} 2)$ from chicken manure under the mesophilic regime of anaerobic fermentation (in vitro). Methods. The study was conducted using laboratory, analytical and mathematical methods. Laboratory methods - to establish the level of greenhouse gas emissions from chicken manure when using different doses of the biological preparation Meganit Nirbator; analytical — to analyze and justify the results; mathematical and statistical - to assess the reliability of research results. Results. Based on the results obtained during the study, it was found that the use of the biological product Meganit Nirbator e-in chicken manure, regardless of the dose activated the process of methanogenesis during the study period, which was confirmed by increasing $\mathrm{pH}$ to 9.2 units. Simultaneously with the higher $\mathrm{pH}$ value in the studied substrate, the introduction of the biological product Meganit Nirbator into chicken manure during anaerobic fermentation (in vitro) under the mesophilic regime caused a higher yield of methane and carbon dioxide: in the variant I - by $11.8 \%$, in the variant II - by $22.9 \%$, in the variant III - by $27.9 \%$, compared with the control. Conclusions. The effective influence of the biological preparation Meganit Nirbator on the emission of greenhouse gases - methane and carbon dioxide from chicken manure under the mesophilic regime of anaerobic fermentation (in vitro) has been experimentally proved and scientifically substantiated. According to the results of research, the most effective influence on the emission of $\mathrm{CH} 4$ and $\mathrm{CO} 2$ has a biological product Meganit Nirbator in a dose of $50 \mathrm{ml}(16.7 \%)$, which increases their quantitative indicators by $22.9 \%$, while increasing the dose of this drug does not significantly affect the yield of the tested gases. Therefore, the biological product Meganit Nirbator can be used as a stimulant to intensify the yield of biogas from chicken manure during processing in biogas plants, thereby minimizing the negative impact of agriculture, in particular poultry, on the environment.
\end{abstract}

Key words: poultry farming, methane, carbon dioxide, anaerobic fermentation, biogas.

DOI: https://doi.org/10.31073/agrovisnyk202102-07

The branch of poultry farming is one of the most developed and progressive branches of agriculture as evidenced by the growing every year the number of poultry of all species the last decade in the world, and in Ukraine, in particular [1-3]. In the main, the most among all different species structures in poultry farming there is a growth in the number of hens. High annual growth rates production of meat poultry in the world are on average 4-6\%, and production of eggs $-1,5-2 \%$ [4]. Domestic producers also constantly increasing their production of eggs and meat poultry, confirmation of what is that Ukraine in 2013 years was included into world top ten producers countries of poultry farming of products [5]. In particular, Ukraine is in the 9th place in the world for production meat of poultry and on 8th for the production of food chicken eggs [6]. The key reasons for the increased production of poultry farming of products are that the last contains the most complete fledged protein as a component part of the ration for the population and represent dietary products and, secondly, the that the branch of poultry farming is characterized by the fastest return with relatively insignificant labor input and forages on a unit of products in comparison with other branches of livestock industries $[1,2,5,7,8]$. It is scientifically proved that for receiving one kilojoules of energy in eggs and meat of poultry necessary to spend twice less fodder units, than by production of milk, and in three times less, than by production of pork and beef [2].

Constant development of the agrarian sector of economy, and branch of poultry farming in particular, leads to an increase in the number of poultry farms which in turn in addition to the main products are meat and eggs, produce also by-products is manure, and in quantities considerably larger, than the main products [1, 3, 9]. At the accumulation of considerable volumes of a chicken manure there are intensive processes of fermentation which cause receipts to the environment of harmful gases (methane, ammonia, hydrogen sulfide etc.) that pose a serious threat to the natural environment, its ecosystems, and also promote global warming $[1,5,7]$. Such negative tendency is the main reason for the deterioration of the conditions for growth and development 
of flora and fauna, of the surrounding the animal world, and ultimately for ecological wellbeing as a whole [10]. Thus, the average anthropogenic load in the territory of Ukraine from waste of poultry farming is 0,22 million $\mathrm{t} / \mathrm{km}^{2}$ and on each one thousand population is 3000 tons [11].

The problem of reliable protection of the natural environment from pollutant of manure and other wastes of poultry farms is an extremely relevant task of the present in modern conditions for all regions of Ukraine, due to the active development of agro-industrial complex, that directly related with growth of waste of the branch $[1,5]$. Taking into account the above, a deep interest in the technology of production of poultry farming of products is the development of new ways of overcoming a problem utilization of chicken manure, which has high energy potential, in particular, by fermentative digestion on alternative energy sources (biogas) [3, 12, 13, 14]. The development of alternative bio-energetics prevents atmospheric pollutions, minimizes the negative influence of agriculture on the environment and provides the non-wastes of production, that is, it receiving high-quality organic fertilizers, energy production, and the neutralization of harmful gases [12, 14-16]. Thus, based on the literature sources and the above, it should be noted that such sector of the economy as agriculture, and poultry farming in particular, are at the same time both a producer of environmental pollution and a potential donor of alternative energy from biomass, that is, it allows to convert a manure from harmful to the environment into profitable and useful product that will give an opportunity to provide high competitiveness of the branch $[15,17]$.

Due to the accumulation of a significant amount of waste in the agro-industrial complex, there is a need to introduce biogas plants, and therefore, the search for ways to intensify the process of methane fermentation $[15,18]$. The research questions of fermentation processes of agricultural wastes is devoted to scientific researchs of a number of scientists, in which highlights the features of biogas production technologies that based on the use of different temperatures, humidity, microbial mass concentration, duration of reaction, etc. $[15,18,19,20]$. One of the most promising ways of intensification the methane fermentation process is the addition of biostimulants, the use of which even in insignificant quantities increases the growth rate of bacteria and the intensity of anaerobic fermentation, that, in turn, increases the efficiency of biogas plants [18, 20]. In the available literature sources provides information on the influence of syntropic association of microorganisms - Sarcina maxima, Sarcina ventriculi, Methanosarcina majei and Methanobacterium thermoautotrophicum on increasing methane output in the processing of agricultural waste, however it is insignificant, that is probably due to the suboptimal selection of bacterial cultures in the proposed association [21]. It is also known that as co-substrates in the bioconversion of waste can be used additives containing trace elements, but the increase in biogas was temporary and insignificant [22, 23]. In the sources of reference and scientific-patent literature it is noted that to intensify the process of methanogenesis used a preparation represented by a complex of trace elements and enzymes, but its broad component composition requires significant costs and time when using it [24]. So, taking into account the above and the importance of solving the problem of chicken manure utilization, the urgent task is to find effective means to stimulate the production of biogas in the processing of waste poultry farms by anaerobic fermentation, which will make it possible to increase the production of additional energy resources - biogas, thereby ensuring the preservation a clean environment for future generations. Therefore, the researches of the processes of anaerobic digestion of chicken manure (in vitro) under mesophilic regime, and also establishing the influence of different doses of biopreparation «Meganit Nirbator» on the volume release of greenhouse gases $\left(\mathrm{CH}_{4}, \mathrm{CO}_{2}\right)$, taking into the pH of level has important scientific and practical importance.

The purpose of the researches is to determine efficiency of the influence of different doses of biopreparation «Meganit Nirbator» on emission of greenhouse gases $\left(\mathrm{CH}_{4}, \mathrm{CO}_{2}\right)$ with chicken manure under mesophilic regime of anaerobic digestion (in vitro).

Materials and methods of the researches. The researches was conducted in the laboratory of ecology of the Institute of agriculture of the Carpathian region NAAS using laboratory - to establish the level of greenhouse gas emissions from chicken manure using different doses of biopreparation «Meganit Nirbator»; analytical - for analysis and substantiation of the obtained results and mathematical-statistical methods - to assess the reliability of research results. For determining efficiency of the influence of different doses of biopreparation «Meganit Nirbator» on emission of greenhouse gases $\left(\mathrm{CH}_{4}, \mathrm{CO}_{2}\right)$ carried out selection the samples of chicken manure of in the FE «West-Bird» of Pustomytiv region of Lviv oblast. Researche was presented in triple repeated in such variants: control - without the introduction of preparation; I variant - with the use of biopreparation «Meganit Nirbator», in dose $25 \mathrm{ml}(8,3 \%)$; Il variant - with the introduction of biopreparation «Meganit Nirbator», in dose $50 \mathrm{ml}(16,7 \%)$; III variant - with the addition of biopreparation «Meganit Nirbator», in dose $75 \mathrm{ml}(25 \%)$.

Biopreparation «Meganit Nirbator» (PC "Eximinvest") consists of composition of 4 bacterial strains are: Azotobacter chroococcum (nitrogen-fixing aerobic bacteria, optimum $\mathrm{pH}$ of 7,0-7,5), Azospirillum Lipoferum (rhizospheric nitrogen-fixing bacterium with an optimum $\mathrm{pH}$ of $7,0-7,5$ and temperature of $20-30{ }^{\circ} \mathrm{C}$ ) $10 \times 10^{9} \mathrm{CFU} / \mathrm{cm}^{3}$; Bacillus subtillis (spore-forming bacterium, which owns an amylolytic property is capable of hydrolyzing polysaccharides to simple carbohydrates, is effective against fusarium, aspergillosis, rhizctonia, phytopathogenic pseudomonas), Bacillus megatherium (rod-shaped bacterium with an optimum pH of 6,5-7,5 and with the temperature of $28-35^{\circ} \mathrm{C}$, has an amylolytic activity, immobilizes phosphorus from complex compounds in the form of $\mathrm{P}_{2} \mathrm{O}_{5}$, has antifungal properties) $10 \times 10^{7} \mathrm{CFU} / \mathrm{cm}^{3}$. 
The process of methane digestion was conducted in vitro at the optimal indexes of digestion according to the method of V. Shatskyy, O. Sklyar, R. Sklyar, A. Solodka [20]. Biomass (chicken manure) diluted with water in corellation of 1:1, was introduced into an experimental a capacity using the flasks closed by stoppers to maintain tightness and providing of anaerobic conditions. During an experiment carried out mixing of the investigated substrate by intensive shaking of the capacities. Identical conditions during the process of methanogenesis were as in the control variant, where the anaerobic digestion of the substrate was due to the natural microflora of chicken manure, as and in the experimental of analogues with the use different doses of biopreparation «Meganit Nirbator».

The acidity was determined using a device pH-Meter Type N5170 (production of Poland). In the investigate substrate the determination of the content of $\mathrm{CH} 4$ and $\mathrm{CO} 2$ was carried out using a signaling device analyzer of gases - a portable Dozor of C-M-5 (certificate of check of the device type UA.TR.001 212-18 and certificate of conformity No. UA.TR.002.CB.1234-19).

The statistical analysis of the obtained results of researches was conducted using variation statistics methods with the help a standard package Microsoft Excel and AtteStat application programs. The arithmetic averages value $(M)$ and an error of arithmetic averages $(m)$ were calculated. The difference between the arithmetic averages values was considered statistically probable at: ${ }^{*} P<0,05 ;{ }^{* *} P<0,01 ;{ }^{* * *} P<0,001$.

Research results and their discussion. The intensity of the anaerobic digestion process depends on the providing of optimal conditions, in particular on the temperature and $\mathrm{pH}$ level etc. Therefore, during in the experiment at every stage of methanogenesis (hydrolysis, oxidation, acetogenesis, methanogenesis) in the investigate material an optimal temperature regime was supported and control of the $\mathrm{pH}$ level of the environment. It is known that the process of methanogenesis can occur in a wide range of temperatures and begins at temperature of $6{ }^{\circ} \mathrm{C}$, whereas at at lower temperature of methane emissions ceases [19], [25]. The research was conducted under a mesophilic regime of fermentation while maintaining the temperature within $33^{\circ} \mathrm{C}$, since given the value of temperature corresponds to the highest metabolic activities of the mesophilic regime, which is the most widespread in spite of the fact that the process of decomposition in the thermophilic conditions is more intensively and the amount of biogas received of $25-30 \%$ higher than in the mesophilic, however thermophilic processes have smaller stability and admissible fluctuations of temperature are significantly reduced [26]. The stability of the process of methanogenesis substantially depends from $\mathrm{pH}$ of the environment, since it is known that when the $\mathrm{pH}$ is reduced to 6,5 , the biogas yield deteriorates by $30-40 \%$, and at $\mathrm{pH} 6,0$ the development of methane microflora is almost completely inhibited [20, 25-27].

At the beginning of formation of methane (the 17th day) at $\mathrm{pH}$ of level 8,35 units in the investigated substrate (chicken manure) was introduced of biopreparation «Meganit Nirbator» in the amount of $25 \mathrm{ml}(8,3 \%), 50$ $(16,7 \%)$ and $75 \mathrm{ml}(25 \%)$. During realization an experiment in the conditions of in vitro, on 17th day and through each three days, carried out determination emission of greenhouse gases $\left(\mathrm{CH}_{4}\right.$ and $\left.\mathrm{CO}_{2}\right)$ with chicken manure in the control and in the experimental analogues with the use of biopreparation «Meganit Nirbator» in different doses.

On the basis of the received results of research, it was established that in the further after introduction in chicken manure of the investigated biopreparation «Meganit Nirbator» growth $\mathrm{pH}$ of level to 9,05-9,2 units was observed depending on the dose, in contrast to the control analogue, that indicates considerable activity of preparation (Fig. 1).

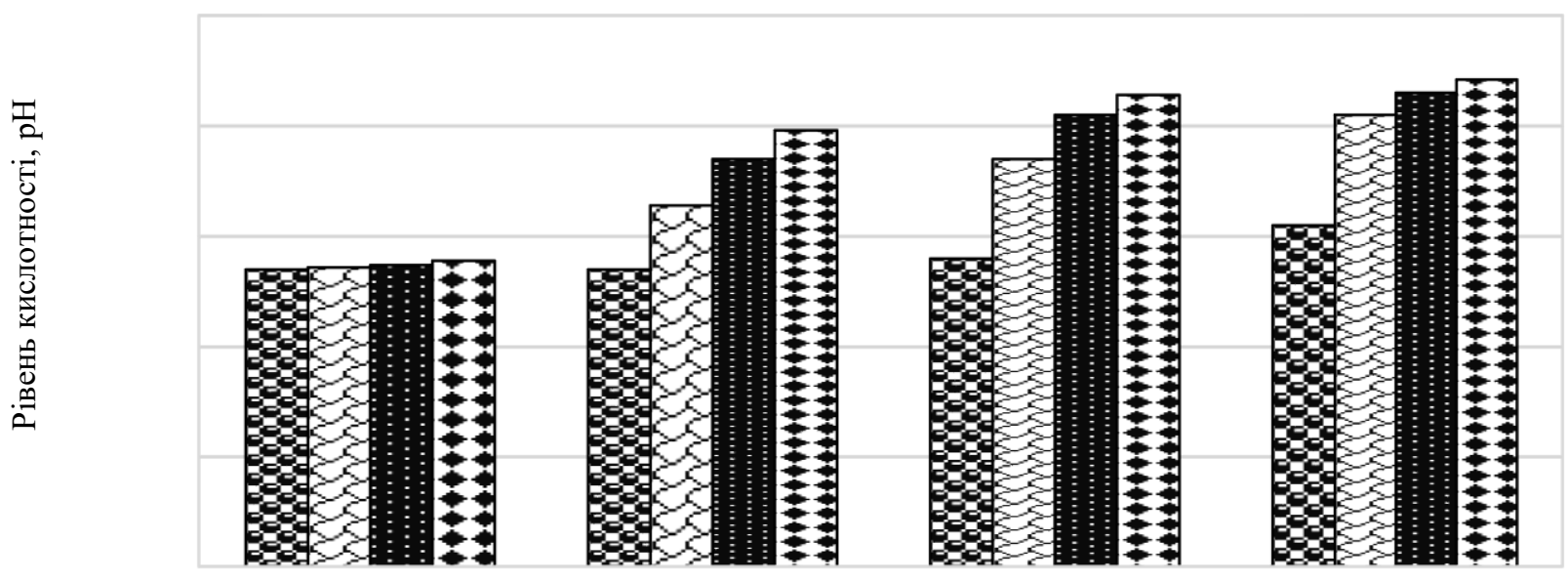

$$
\begin{aligned}
& \text { Період досліду, доби }
\end{aligned}
$$

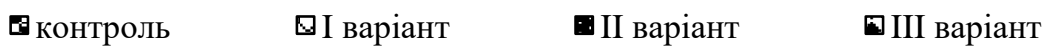

Fig. 1. Change the level of acidity in variants with use of biopreparation «Meganit Nirbator» in different doses (I - $25 \mathrm{ml}(8,3 \%)$, II - $50 \mathrm{ml}(16,7 \%)$, III - $75 \mathrm{ml}(25 \%)$ ) in the process of methanogenesis 
Analyzing results the experimental of researches it was established that in the investigated variants with use of biopreparation «Meganit Nirbator», at the same time with increase $\mathrm{pH}$ of the environment in chicken manure at anaerobic digestion (in vitro) under mesophilic regime was observed the growth of an output of greenhouse gases is methane and carbonic gas.

According to the results of the conducted researches it was established that use of biopreparation «Meganit Nirbator» in different doses $25 \mathrm{ml}(8,3 \%), 50(16,7 \%)$ and $75 \mathrm{ml}(25 \%)$, activation the process of methanogenesis, causes a higher output of methane and carbonic gas, in comparison with the control by $11,8 \%, 22,9$ and $27,9 \%$ (Fig. 2, 3).

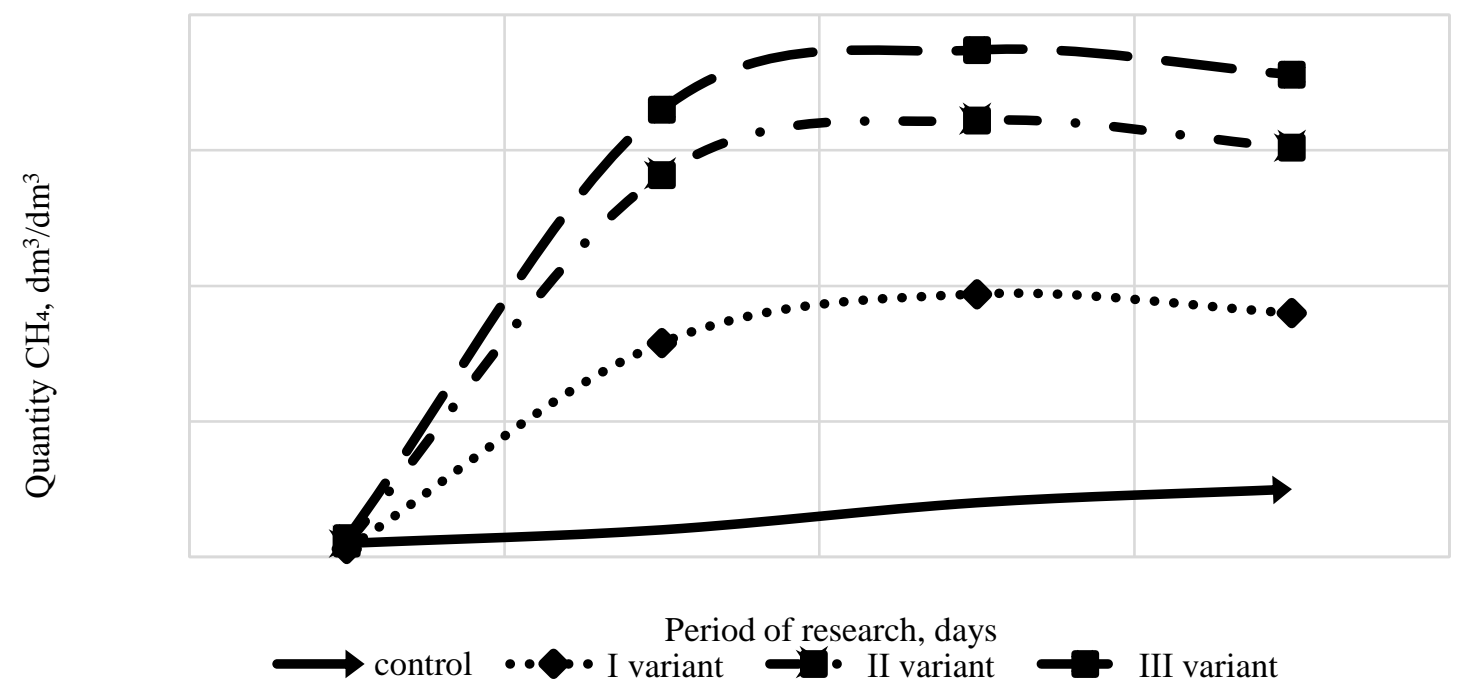

Fig. 2. Quantity of methane selected in variants with use of biopreparation «Meganit Nirbator» in different doses (I - $25 \mathrm{ml}(8,3 \%)$, II - $50 \mathrm{ml}(16,7 \%)$, III - $75 \mathrm{ml}(25 \%)$ ) in the process of methanogenesis

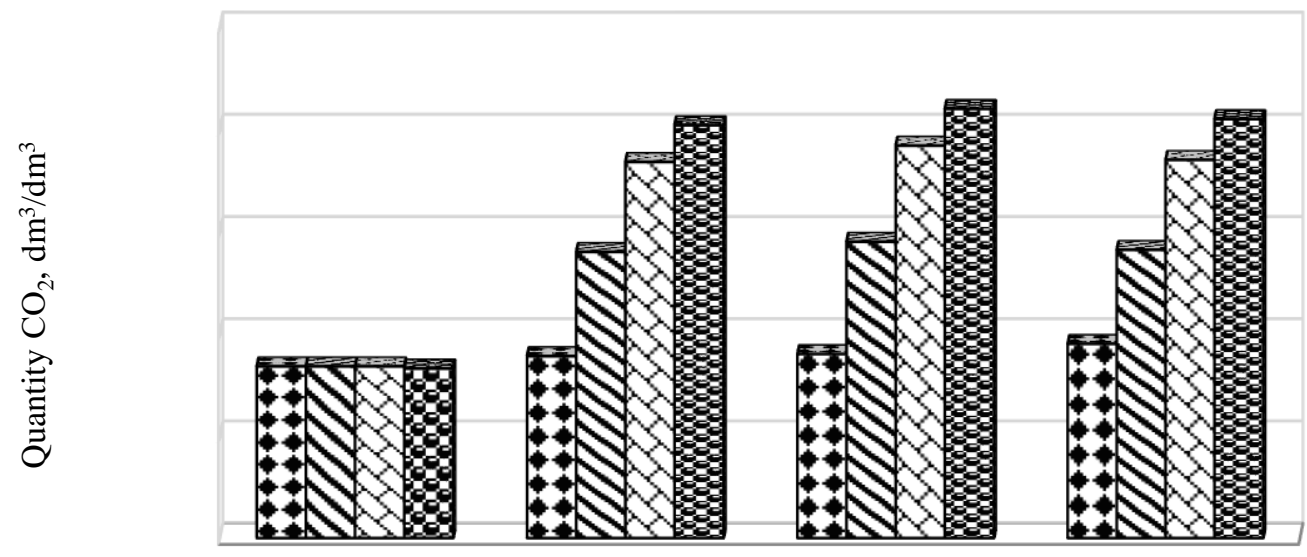

$$
\begin{array}{lll}
\text { Period of research, days } & \\
\mathbf{0} \text { control } & \boldsymbol{Q} \text { I variant variant }
\end{array}
$$

Fig. 3.

Quantity of carbonic gas selected in variants with use of biopreparation "Meganit Nirbator» in different doses (I - $25 \mathrm{ml}(8,3 \%)$, II - $50 \mathrm{ml}(16,7 \%)$, III - $75 \mathrm{ml}(25 \%)$ ) in the process of methanogenesis

Therefore, experimentally it is proved that the introduction of biopreparation «Meganit Nirbator» in chicken manure under mesophilic regime digestion in the anaerobic conditions regardless of a dose (25 $\mathrm{ml}(8,3 \%), 50$ $(16,7 \%)$ and $75 \mathrm{ml}(25 \%))$ increases of output $\mathrm{CH}_{4}$ and $\mathrm{CO}_{2}$ during in the investigated period and after 26 days the level at emission of the above gases became stable. In particular, at the increased dose of the investigated preparation twice $(50 \mathrm{ml}(16,7 \%))$ quantitative indexes of methane and carbonic gas were growing by $11,1 \%$ whereas triple increase in the dose of preparation $(75 \mathrm{ml}(25 \%)$ ) causes higher level of the investigated gases by only $5 \%$ at anaerobic digestion in chicken manure, that is has no significant effect and is not economically expedient. 
Growth of the content of $\mathrm{CH}_{4}$ and $\mathrm{CO}_{2}$ for the addition of biopreparation «Meganit Nirbator» indicates on the efficiency of its use for the activation of anaerobic fermentative activity. Therefore, of biopreparation «Meganit Nirbator» can be used as a stimulator the intensification the output of biogas at processing byproducts of animal origin for efficient functioning biogas plants, thereby preventing pollution of the natural environment.

\section{Conclusions}

Efficiency action on the process of methanogenesis and emission of greenhouse gases $\left(\mathrm{CH}_{4}\right.$ and $\left.\mathrm{CO}_{2}\right)$ with chicken manure of biopreparation "Meganit Nirbator» under mesophilic regime in the anaerobic conditions was established. The use in the investigated substratum of such preparation in a dose $25 \mathrm{ml}(8,3 \%)$ are caused by growth in the level of $\mathrm{CH}_{4}$ and $\mathrm{CO}_{2}$ by $11,8 \%$, and at introduction of $50 \mathrm{ml}(16,7 \%)$ and $75 \mathrm{ml}(25 \%)$ an output of the investigated gases was higher, respectively, by $22,9 \%$ and $27,9 \%$ in comparison with control. Therefore, it is advisable to use of biopreparation "Meganit Nirbator» for activation the process of methanogenesis in chicken manure in biogas plants for the purpose increase an output of biogas.

In future, it is planned to conduct experimental research of the process of anaerobic digestion of chicken manure (in vivo) at the use of biopreparation «Meganit Nirbator» and to search for effective means and methods for reducing pollution of the environmental by waste of poultry farming, that will minimize the negative of the influence activity enterprises of the agro-industrial complex.

\section{References}

1. Dutka, D.I. (2018). Do pytannia povodzhennia z orhanichnymy vidkhodamy ptakhofabryky [On the issue of organic waste management of poultry farm]. Ekolohiia ta stalyi rozvytok: materialy III Naukovopraktychnoi konferentsii [Ecology and sustainable development: Materials III of the scientific and practical conference]. (pp. 78-81). Ukraine, Mariupol. [in Ukrainian].

2. Ivko, I.I., Melnyk, V.O., Pudov, V.Ya., Riabinina, O.V., Duiunov, E.E., Horbanov, A.P. Kulbaba, S.V., \& Chaplyhin, Ye.M. (2009). Udoskonalennia tekhnolohii vyrobnytstva produktsii ptakhivnytstva: retrospektyva i perspektyvy [Improvement of production technologies of products of poultry farming: retrospective and prospects]. Poultry farming, 64, 11-23. [in Ukrainian].

3. Rybakova, O.A. (2015). Oblikovi aspekty oprybutkuvannia i vykorystannia ptashynoho poslidu [Registration aspects of receipt and use of birds manure]. Agroworld. 19, 72-77. [in Ukrainian].

4. Tsyhanok, V.M., \& Hulia, Yu.V. (2011). Analiz vyrobnytstva produktsii ptakhivnytstva v umovakh rynkovykh peretvoren [Analysis of production of poultry farming products in the conditions of market transformations]. Bulletin of ZhNAU, 1 (2), 276-287. [in Ukrainian].

5. Boiko, L.O., Boiko, V.O., \& Avercheva, N.O. (2016). Rozrobka prohnozu ta perspektyvy rozvytku haluzi ptakhivnytstva do 2020 roku [Development of the forecast and the prospect of development of the branch of poultry farming by 2020]. Technology audit and production reserves, 4/6 (30), 34-40. [in Ukrainian].

6. Buriak, R.I. (2017). Doslidzhennia ta prohnozuvannia koniunktury rynku produktsii ptakhivnytstva Ukrainy [Research and forecasting of the market situation of poultry farming of products in Ukraine]. Scientific bulletin NUBiP, 260, 41-53. [in Ukrainian].

7. Duranova, T.A. (2010). Suchasnyi stan ta perspektyvy rozvytku ptakhivnytstva [Current status and prospects of development of poultry farming]. Bulletin of social and economic researches, 38, 259-264. [in Ukrainian].

8. Polehenka, M.A. (2019). Analiz suchasnoho stanu vyrobnytstva produktsii ptakhivnytstva v Ukraini [An analysis of the current state of poultry production in Ukraine]. Economy and state, 3, 137-143. [in Ukrainian]. doi:10.32702/2306-6806.2019.3.137.

9. Ishchenko, K.V. (2019). Doslidzhennia parametriv mikroklimatu ptashnykiv ta khimichnogo skladu poslidu kurei za vykorystannia klitkovykh batarei z riznymy systemamy povitrovydalennia [Researches of parameters of a microclimate of poultry farm and the chemical composition of chickens manure for use of cellular batteries with different air removal systems]. Scientific and technical bulletin IA, 121, 127136. [in Ukrainian].

10. Lysenko, V.P., Tiurin, V.G., Mysova, H.A., Biriukov, K.N., Potemkina, N.N., Andreev, R.Yu., Lopata, F.F., \& Avylov, Ch.K. (2011). Veterinarno-sanitarnye i ekologicheskie usloviia pri pererabotke pticheho pometa [Veterinary and environmental conditions at the processing of chicken manure]. Poultry and poultry products, 3, 13-16. [In Russian].

11. Yashchenko, S.V. (2010). Ekolohichna otsinka ochystky ta znezarazhennia stichnykh vod ptakhokompleksu [Ecological assessment of purification and external treatment of sewage of poultry farm]. NTB IBA and SNRCI vet. preparation and feed additives, 11(2/3), 328-331. [in Ukrainian].

12. Dere, A.J., Kalbande, S.R., \& Khambalkar, V.P. (2017). Recent review on biogas production from different waste. International Journal of Current Microbiology and Applied Sciences, 6 (10), 3452-3457. doi:10.20546/ijcmas.2017.610.407.

13. Ziemiński, K., \& Frąc, M. (2012). Methane fermentation process as anaerobic digestion of biomass: Transformations, stages and microorganisms. African Journal of Biotechnology, 11 (2), 4127-4139. doi:10.5897/AJBX11.054. 
14. Wang, F., Pei, M., Qiu, L., Yao, Y., Zhang, C., Qiang, H. (2019). Performance of anaerobic digestion of chicken manure under gradually elevated organic loading rates. Int J. Environ. Res. Public Health, 16 (12), 2239-2246. doi:10.3390/ijerph16122239.

15. Boltianskyi, B.V., Dereza, O.O., \& Dereza, S.V. (2019). Sposoby utylizatsii vidkhodiv tvarynnytstva i ptakhivnytstva [Ways of utilization of livestock and poultry farming waste]. Suchasni naukovi doslidzhennia na shliakhu do yevrointehratsii: materialy mizhnarodnoho naukovo-praktychnoho forumu [Modern scientific researches on the way to European integration: materials of the International scientific and practical forum]. (pp. 214-217). Ukraine, Melitopol. [in Ukrainian].

16. Adekunle, K.F., \& Okolie, J.A. (2015). A review of biochemical process of anaerobic digestion. Advances in Bioscience and Biotechnology, 6, 205-212. doi:10.4236/abb.2015.63020.

17. Makhovskyi, D.V. Problemy innovatsiinoho rozvytku ptakhivnytstva [Problems of innovative development of poultry farming]. Aktualni problemy: teoretychni ta praktychni aspekty: materialy Mizhnar. nauk.-prakt. Internet-konfer. mol. nauk., aspir. ta stud. [Current problems: theoretical and practical aspects: Materials Intern. scientific and practical Internet conference of young scientists, graduate students and students]. (pp. 167-168). Ukraine, Kamianets-Podils. [in Ukrainian].

18. Skliar, O.H., \& Skliar, R.V. (2014). Metody intensyfikatsii protsesiv metanovoho zbrodzhuvannia [Methods of intensification of methane fermentation processes]. Scientific bulletin of TSATU, 4 (1). 3-9. [in Ukrainian].

19. Solyk, H.S, Butsiak, V.I., \& Butsiak, A.A. (2015). Biotekhnolohiia vyrobnytstva biohazu z vidkhodiv silskohospodarskoho vyrobnytstva [Biogas production from biotechnology agricultural activities]. Scientific bulletin LNUVM and BT of the name S. Z. Gzhytskoho, 17 (3 (63)), 312-319. [in Ukrainian].

20. Shatskyi, V.V., Skliar, O.H., Skliar, R.V., \& Solodka, O.O. (2013). Vplyv struktury substratu na vykhid biohazu pry metanovomu zbrodzhuvanni [Influence of substrate structure on biogas output at methane fermentation]. Proceedings of the TSATU, 13 (3), 3-12. [in Ukrainian].

21. Tretiakova, V.P., Zhilina, T.Ya., Kozhevnikova, A.N., Melnik, R.A., \& Evdokimenko, I.I. Patent. no. 1049537A Russia, 636.220.18: 547.211.862 (088.8). Sintrofnaia assotsiatsiia mikroorganizmov Sarcina maxima, Sarcina ventriculi, Methanosarcina majei i Methanobacterium thermoautotrophicum No. 1001 dlia pererabotki organichesnikh otkhodov selskoho khaziaistva $v$ metan [Syntrophic association of microorganisms Sarcina maxima, Sarcina ventriculi, Methanosarcina majei and Methanobacterium thermoautotrophicum no. 1001 for the processing of organic agricultural waste into methane]; Applicant and patent VNIIKPMZhK; no. 3460549/30-15; stated 29.06.82; posted by 23.10.83. Bul. no. 39. [In Russian].

22. Eder, B., \& Shults, Kh. (Reddih, I.A. (Ed.)) (1996). Biohazovyie ustanovki. Prakticheskoe posobie [Biogas plants. Practical guide]. [In Russian].

23. Holper, J., Lesjak, M., Heinzel, U., \& Boos, B. Patent. no. EP 1577269A1 Deutschland, Int Cl. C02F 11/04, C02F 3/28. Zeolith in der Biogasgewinnung.; anmelder: IPUS Industrie-, Produktions- und Umwelttechnisches Service GmbH, 8786 Rottenmann (AT); no. 05450052.5; anmeldetag 17.03.2005; veröffentlichungstag 21.09.2005. Patentblatt 2005/38.

24. Weiwei, L., Huan, M., Zhiliang, Y., Chengmao, C., Yingchun, Y., Lei, Q., \& Wenming, Z. Patent. no. CN 102876725A China, IPC C12P 5/02 (2006.01), C02F 11/04 (2006.01). Active compound additive for promoting fermentation of methane and use method thereof. no. 201210355799; stated 18.09.2012; posted by 16.01.2013.

25. Vorobel, M.I., Moroz, V.V., \& Kaplinskiy, V.V. (2018). Efektyvnist dii pryrodnykh mineraliv na emisiiu parnykovykh haziv u hnoievomu substrati [Efficiency the action of natural minerals on the emission of greenhouse gases in the manure substrate]. Bulletin of Agricultural Science, 10, 35-40. [in Ukrainian]. doi:10.31073/agrovisnyk201810-05.

26. Polishchuk, V.M., Lobodko, M.M., Sydorchuk, O.V., \& Polishchuk, O.V. (2013). Vplyv rezhymiv metanovogo brodinnia na efektyvnist vyrobnytstva biohazu [Influence the regimes of methane fermentation on efficiency biogas production]. Scientific bulletin NUBiP, 185 (3), 180-191. [in Ukrainian].

27. Li, Y., Zhang, R., Chen, Ch., Liu, G., Liu, G., He, Y., \& Liu, X. (2013). Biogas production from codigestion of corn stover and chicken manureunder anaerobic wet, hemi-solid, and solid state conditions. Bioresource Technology, 149, 406-412. doi:10.1016/j.biortech.2013.09.091. 